\title{
Is colonialism history? The declining impact of colonial legacies on African institutional and economic development
}

\author{
ROBBERT MASELAND* \\ University of Groningen, The Netherlands; Melbourne Business School, Australia
}

\begin{abstract}
This paper investigates the claim that colonial history has left an enduring imprint on Africa's institutional and economic development. The literature following Acemoglu, Johnson and Robinson (2001) and Sokoloff and Engerman (2000) maintains that different types of colonialism affected the institutional environment differently, and that path-dependence subsequently ensures that these institutional differences and their impact on economic performance are persistent over time. By tracing the impact of colonial institutions on contemporary institutions over time, I show that - in contrast to claims in this literature - the relevance of colonial legacies to institutional quality and to per capita income is rapidly disappearing in Africa. Differences in institutional quality or income are explained less and less by colonial legacy, while there is some evidence that precolonial social and geographical circumstances are becoming more important. I conclude that while colonialism has affected African institutional and economic development significantly, this impact is not persistent. Rather, the evidence suggests that colonialism has created a large but very temporary institutional shock, after which a long-run equilibrium is being restored.
\end{abstract}

\section{Introduction}

Now that it has been firmly established that institutions matter in development, the literature has increasingly focused on the question of where 'good' institutions come from. Among the broad set of deep determinants identified in the literature (Spolaore and Wacziarg, 2013), the colonial origins of institutions and development have perhaps been discussed most extensively (Acemoglu et al., 2001; Bertocchi and Canova, 2002; Michalopoulos and Papaioannou, 2016; Sokoloff and Engerman, 2000). By and large, this literature has argued that differences in colonization practices, be it in terms of the identity of the colonizer or of the pattern of colonization, have a persistent effect on development. The mechanism through which colonial history continues to have this effect

*r.k.j.maseland@rug.nl 
is through its impact on domestic institutions (Acemoglu et al., 2001, 2005; Engerman and Sokoloff, 1997; La Porta et al., 1997, 1998; Nunn, 2014; Sokoloff and Engerman, 2000). Initial shocks such as colonization trigger a path-dependent institutional evolution that has an impact long after the initial event has ended (Spolaore and Wacziarg, 2013). The kind of institutions a country faces today are thus strongly determined by its history, colonial or otherwise.

Yet in spite of extensive evidence that history matters in current institutions (Nunn, 2014), the literature offers few insights into the degree of persistence of historically established institutions. Typically, literature in this area is crosssectional, relating institutional and economic outcomes today to determinants such as colonial history (Acemoglu et al., 2001; Bertocchi and Canova, 2002; Dell, 2010). This tells us that colonial history still has an identifiable effect on contemporary societies. Given the relatively recent end of colonial relationships and the sizable impact of colonialism on colonized societies, that is in itself not very surprising. At least as interesting, but yet unanswered, is the question how persistent this impact is. Has colonization set countries on an irreversible evolutionary path? How long can we expect countries to be burdened by their colonial past?

These questions are perhaps nowhere more pressing than in the context of Africa, which as a region continues to lag behind in terms of economic development. Though African development is often hindered by weak or extractive institutional frameworks, differences within the region are profound. Star-performers like Botswana or Mauritius provide a stark contrast with places like Congo Kinshasa or Madagascar, which are plagued by a post-colonial history of predatory regimes, repression and violence. If part of this discrepancy in performance can be explained by differences in colonial history and resulting institutional quality (Robinson et al., 2003; Subramanian, 2013) it is important to know whether we can expect these effects to persist or whether they are likely to disappear in the near future.

This paper takes up this question, studying the evolution of the effects of colonial legacies on institutional quality and economic development since independence. It does so on the basis of a panel analysis, estimating reduced form regressions of institutional indicators (taken from the Polity IV dataset) and per capita income on a set of variables capturing colonial legacies and interacting colonial legacy variables with post-colonial country age. I confirm the literature's claim that colonial history matters to institutions, though I find only partial support for such effects on income. What is more, I show that institutional and income effects are declining with age, with the institutional impact reaching statistical and economic insignificance within two decades. In its place, the effects of social and geographical conditions are playing up, suggesting that a more fundamental political-economic equilibrium preceding colonial intervention is being restored. Results are robust to various changes in 
specifications and samples. I conclude that colonial history has mattered, but it is increasingly a thing of the past.

\section{Background}

The debate about the effects of colonialism on colonized societies is almost as old as colonialism itself. Confronted with increasing critique about the conditions of colonized peoples (e.g. Multatuli 1860), colonial powers in the $19^{\text {th }}$ century started legitimizing their rule over foreign lands and peoples by claiming to be on a civilizing mission (Fischer-Tiné and Mann, 2004). From this perspective, colonial rule existed not only for the benefit of the colonial powers, but was supposed to be in the interest of all the empire's subjects. The 'white man's burden' (Kipling, 1899) was to bring civilization, technology and progress to parts of the world that would otherwise go without.

While colonial rule was generally legitimized by the idea that it was benevolent, different varieties of colonialism were argued to have different impacts on colonized societies, some more favourable than others (Fieldhouse, 1966). British politicians saw the British Empire as spreading the values of individual freedom and commerce around the world. In contrast, the harsh and unabashedly extractive rule of King Leopold's Congo Free State triggered a strong public campaign (Conan Doyle, 1909; Conrad, 1899), which ultimately led other colonial powers to push Belgium to adopt a more 'civilized' form of colonization in Belgian Congo. In addition, British colonial administrators and imperial scholars typically maintained that British specialization in indirect rule was superior to directly ruled colonies, as it was supposed to be more responsive and inclusive and less disruptive (Lange, 2004).

When colonialism went out of fashion, such arguments persisted. A large literature has emerged linking various characteristics of colonialism to differences in economic growth or political development after independence. A number of authors have argued that British imperialism, for all its faults, produced better outcomes for its colonies than rival colonial empires (Bertocchi and Canova, 2002; Grier, 1997; Klerman et al., 2011; La Porta et al., 1998; Lee and Schultz, 2012; North, 2006) because of the superior adaptability of British legal institutions or the supposed emphasis on freedom in British culture. Some have gone further, claiming that the British imperialist project was a necessary evil to bring about the greater good of modernity (Ferguson, 2012).

In the same vein, the proposition that indirect rule produced superior results was turned around into the claim that direct rule had been more beneficial, as it had introduced more of Europe's superior institutions to the colonies (Lange, 2004, 2009). The idea that indirect rule left the social fabric intact was abandoned. Indirect rule was now supposed to have created deep divisions in societies, and have blocked the development of effective central administrations (Lange, 2009). Following their seminal paper (Acemoglu et al., 2001), Acemoglu 
and Robinson adapted the opposition between direct and indirect colonial rule into the notion of extractive versus inclusive forms of colonization (Acemoglu and Robinson, 2013). In their view, colonies with larger settler populations developed more inclusive institutions, as their administrations were less focused on extracting rents from the colonies' populations and more on serving their interests.

The idea that colonial rule produced positive long-term outcomes is also reflected in a small literature focusing on the duration of colonization. A separate argument evolved around the length of colonial rule. Grier (1999) shows that longer exposure to colonial rule is related to higher post-independence growth rates. Obviously, this correlation may reflect the earlier colonization of territories that were more profitable, rather than a causal effect of colonialism duration. To address this, Feyrer and Sacerdote (2009) use currents and winds as instruments for the start of colonization of a sample of island nations, finding that longer periods of colonial rule produce higher long-term growth.

This literature on colonial legacies may be criticized for ignoring autonomous political-economic developments in colonies and overemphasizing the impact of European imperial powers on institutional history in colonial societies. In response to this, a number of authors have started to stress precolonial institutional development and its interaction with colonialism as equally, if not more important (Englebert, 2000; Gennaioli and Rainer, 2007; Michalopoulos and Papaioannou, 2013, 2016; Nunn, 2008). Gennaioli and Rainer (2007) still herald the modernizing force of colonialism as crucial, but argue that modernization progressed further where it could build on more developed precolonial institutional systems. Others have stressed the compatibility of precolonial with colonial institutions, arguing that a higher degree of conflict between the two created worse outcomes in the long run (Englebert, 2000; Michalopoulos and Papaioannou, 2016). Nunn (2008), focusing on the impact of slavery, and Michalopoulos and Papaioannou (2013), focusing on centralized authority structures, simply highlight the continued importance of precolonial institutions to outcomes today. Both argue that these are more fundamental determinants of institutional and economic development than colonialism has been.

\section{Institutional persistence}

In different ways, all the literature about the importance of colonial and precolonial legacies stresses the persistence of institutional development. Whether colonialism is seen as force for good (Ferguson, 2012) or bad (Michalopoulos and Papaioannou, 2016), the central claim is that its impact continues to profoundly affect African societies to the present day. Interestingly enough, the mechanism through which colonial legacies are reproduced over time are rarely discussed in this literature. 
More general theoretical arguments about institutional persistence highlight path-dependence through cultural transmission (North, 2006), biological transmission (Ashraf and Galor, 2013; Putterman and Weil, 2010), or politicaleconomic transmission (Acemoglu et al., 2005). In the first two arguments, economic institutions are embedded in underlying, deep-rooted values, beliefs and the natural characteristics of societies, which limit the propensity for radical institutional change (North, 2006; Williamson, 2000). The biological transmission argument suggests that certain environmental characteristics, such as disease prevalence, have a direct effect on behavioural norms in a population (Fincher et al., 2008; Maseland, 2013). A more controversial version maintains that the biological characteristics of populations themselves have such effects (Ashraf and Galor, 2013; Gorodnichenko and Roland, 2016). More widely accepted is the idea of cultural transmission (Fernández and Fogli, 2006). In this light, North (2006) stresses the symbiotic evolution between ideas and institutions, arguing that the knowledge and ideas a society develops are a response to the incentives and mental models created by its institutional system, while changes to the institutional system are a product of new ideas. Williamson (2000) maintains that the stability of deep-rooted cognitive and normative structures on which institutions depend ensures the persistence of institutional differences. From such a perspective, the continuing impact of colonial legacies is explained by arguing that imperial powers not only introduced certain formal institutions to their colonies, but also left a strong imprint on the values, norms and cognitions. Even though independence has brought states the formal power to radically change institutions, such informal constraints have largely stopped them from doing so.

Acemoglu et al. (2005) see the roots of institutional persistence in the interdependent relation between economic institutions and the distribution of de jure and de facto power. Their core argument is that economic institutions affect the distribution of resources, which may be invested in gaining political influence. More political influence, in turn, allows one to define the direction of change in economic institutions, normally further increasing the bias towards incumbent elites. In this argument, a colonial legacy that has set countries on a path of extractive institutions will have an enduring effect, as the post-colonial elites benefiting from this institutional system are capable of reproducing and willing to reproduce this system perpetually. By contrast, colonies that have been blessed with inclusive institutions enter a different dynamic, in which open access to the decision making process ensures persistently superior institutions (cf. North et al., 2009).

This view of colonial legacies continuing to plague African development has not gone unchallenged, however. Young (2004) argues that, if colonialism ever played a defining role in the lives of African societies, this role effectively ended by the 1990s. By that time, African institutional development was no longer dominated by what had been imported from 
the colonial powers, but influenced by autonomous, internal processes and conflicts.

Confronted with a literature stressing the continued importance of colonial legacies on the one hand, and Young's (2004) announcement of the end of the post-colonial era on the other, what do the data say? So far, very little. Studies about the impact of colonial legacies typically are cross-sectional in nature, and do not address the evolution of colonial influence. The literature's main insight is that differences in colonialism partially explain differences in development between post-independence African societies. Given the sizable impact of colonial rule and the relatively recent end of it, the opposite would be more surprising. Few studies have traced the evolution of this impact of colonial legacies. Therefore, the main claims in the colonial legacies literature - that British colonial origins, longer periods of colonial rule and higher shares of settlers produce persistently superior development outcomes - are as yet untested. To remedy this, I analyse the temporal stability of the effects of these characteristics on institutional and economic development in former African colonies. On basis of the colonial legacies literature, I formulate the following hypotheses:

Hypothesis 1a: the positive effect of British colonial legacy on institutional quality in former African colonies is stable over time.

Hypothesis 1b: the positive effect of longer duration of colonization on institutional quality in former African colonies is stable over time.

Hypothesis 1c: the positive effect of European settlers on institutional quality in former African colonies is stable over time.

Hypothesis 2a: the positive effect of British colonial legacy on per capita income in former African colonies is stable over time.

Hypothesis 2b: the positive effect of longer duration of colonization on per capita income in former African colonies is stable over time.

Hypothesis 2c: the positive effect of European settlers on per capita income in former African colonies is stable over time.

\section{Data and method}

In order to assess the evolution of any colonial legacy effects, I start out with an intuitive, illustrative approach. The first step is to identify a number of variables capturing various dimensions of the colonial legacy and to relate these to both institutional quality and (logged) per capita income levels in a series of regressions. Repeating this procedure for each period since independence (i.e. for each country age) and plotting the coefficients gained in step one against country age allows me to make a first assessment of whether the impact of colonialism on institutional quality and per capita income is stable, increasing or receding, and, in the latter case, at what point it time it becomes insignificant. 
While the repeated regression approach has intuitive appeal, a more rigorous approach to the question at hand is a panel analysis. I regress institutional quality and economic development indicators on the three dimensions of colonial legacy. Since my main interest lies in the evolution of the impact of colonial legacies over time, I interact the time-invariant legacy variables with the length of time since country was a colonial state. This translates into the following estimated function:

$Y_{i t}=\alpha+\beta \operatorname{Legacy}_{i}+\Phi A_{i t}+\gamma \operatorname{Legacy}_{i} \cdot A_{i t}+\theta x_{i t}^{\prime}+\mu z_{i}^{\prime}+\sum_{1960}^{2015} \rho_{j} I_{t}^{j}+u_{i}+\epsilon_{i t}$,

in which $i$ indexes countries and $t$ indexes time. The outcome $Y_{i t}$ is either institutional quality or the natural logarithm of per capita income. Legacy is a vector of colonial legacy variables, specifically duration, identity of colonizer and proportion of settlers. The variable $A_{i t}$ denotes the age of post-colonial states. The terms $\theta x_{i t}^{\prime}$ and $\mu z_{i}^{\prime}$ reflect vectors of time-variant and time-invariant control variables. Country-specific random effects are included by $u_{i}$. Since independence has not come about at the same time for all countries, comparing by age implies comparing countries at different points in time. For example, when assessing institutional quality for countries aged 10, I am comparing Nigeria in 1970 with Mozambique in 1985. This approach best reflects the idea of tracking the degree of persistence of colonial legacies, but it may raise concerns about time effects. To address this, I include year-fixed effects $\sum_{1960}^{2015} \rho_{j} I_{t}^{j}$ in the analysis as well (1960 being the first year for which income data are available).

I am mainly interested in the value of $\gamma$. This coefficient gives me an estimate of the temporal stability of the legacy effect on institutional quality or economic development. When the coefficient on the interaction variable is significant and opposite to the initial legacy effect, this suggests that any effect of colonialism is receding. When the interaction term is not significant, this suggests that any effect of colonial legacies is unchanging over time.

When assessing the evolutionary trajectories since independence, I limit the analysis to the period that is still observed in each country of the sample, so as to keep the sample constant across age groups. This implies that, given the independence date of Zimbabwe (1980) as the last country in the sample to end colonial rule, the analysis is restricted to 35 years of observed evolution since independence. While constant samples are required for a meaningful comparison, they come at the expense of information about countries that have been independent for much longer than Zimbabwe. As an alternative, I therefore conduct the same analysis for the smaller set of countries that gained independence before 1970. This limits the number of countries in the sample, but ensures I can assess their trajectory for 45 years, maximizing the number of country-year observations. Note that taking decolonization before 1970 excludes 
all Portuguese colonies in Africa, which likely biases the results. For this reason, this is not my preferred model. Taking any cut-off point before 1970 would extend the trajectories even more, but would limit the number of countries even further and reduce the number of country-year observations. Table 1 provides the lists of countries included in both samples.

\section{Dependent variables}

As a measure of institutional quality, I use the indicator of constraints on the executive taken from Polity IV (Marshall et al., 2016). This dataset runs from 1800 until 2015 and is the only widely used institutional data source available for each year since independence. The executive constraint variable has been used as an indicator for expropriation risk and shown to be capturing the most important element of institutional quality (Acemoglu and Johnson, 2005; Acemoglu et al., 2001; Bertocchi and Canova, 2002). The index runs from 1 to 7 , with a score of 1 reflecting unlimited executive authority and a score of 7 executive parity of subordination. Conforming to the Polity IV manual, country years without a functioning authority have been given the neutral score (4), while yearly interpolation has been used to predict values in years of transition and foreign interruption. A potential problem of using the executive constraint variable is that it is truncated at the low and high ends. For the specific purposes of this paper, a concern may be that in case of a general trend towards more executive subordination, the explanatory power of any determinant will decrease over time because the countries with the 'highest' institutional quality are not able to rise further due to scale limits, while the others are catching up. To partially control for this effect, I standardize the variable per age level. To assess economic performance, I use the natural log of income per capita levels, taken from the Penn World Tables (Feenstra et al., 2015). This variable is available for independent polities since 1960 .

\section{Colonial legacy}

I use three different variables to capture three dimensions of colonial legacies. First, I assess colonial identity by using a dummy variable for British colonial origins. This variable reflects the observation that countries with British legacies on average perform better than other countries (Bertocchi and Canova, 2002; Grier, 1997; La Porta et al., 2008).

The second variable captures the mode of colonialism, inclusive or extractive. The distinction between settler colonies, setting up an inclusive institutional framework, and extractive colonial administrations, denying economic freedoms to citizens, is captured by the share of European settlers in the colonial population (Acemoglu et al., 2001).

The third variable I use is the duration of colonization, which has been argued to be related to development (Grier, 1999). Longer colonial involvement is likely to translate into a larger transfer of human capital and institutional innovations 
Table 1. Countries included in analysis of post-colonial development

\begin{tabular}{|c|c|}
\hline Full sample & Limited sample (gained independence before 1970) \\
\hline Algeria & Algeria \\
\hline Angola & Benin \\
\hline Benin & Botswana \\
\hline Botswana & Burkina Faso \\
\hline Burkina Faso & Burundi \\
\hline Burundi & Cameroon \\
\hline Cameroon & Central African Republic \\
\hline Central African Republic & Chad \\
\hline Chad & Congo Brazzaville \\
\hline Congo Brazzaville & Congo Kinshasa \\
\hline Congo Kinshasa & Equatorial Guinea \\
\hline Djibouti & Gabon \\
\hline Equatorial Guinea & Gambia \\
\hline Gabon & Ghana \\
\hline Gambia & Guinea \\
\hline Ghana & Ivory Coast \\
\hline Guinea & Kenya \\
\hline Guinea-Bissau & Lesotho \\
\hline Ivory Coast & Madagascar \\
\hline Kenya & Malawi \\
\hline Lesotho & Mali \\
\hline Madagascar & Mauritania \\
\hline Malawi & Morocco \\
\hline Mali & Niger \\
\hline Mauritania & Nigeria \\
\hline Morocco & Rwanda \\
\hline Mozambique & Senegal \\
\hline Niger & Sierra Leone \\
\hline Nigeria & South Africa \\
\hline Rwanda & Sudan \\
\hline Senegal & Swaziland \\
\hline Sierra Leone & Tanzania \\
\hline South Africa & Togo \\
\hline Sudan & Tunisia \\
\hline Swaziland & Uganda \\
\hline Tanzania & Zambia \\
\hline \multicolumn{2}{|l|}{ Togo } \\
\hline \multicolumn{2}{|l|}{ Tunisia } \\
\hline \multicolumn{2}{|l|}{ Uganda } \\
\hline \multicolumn{2}{|l|}{ Zambia } \\
\hline Zimbabwe & \\
\hline
\end{tabular}

from Europe to the colonies. What is more, the duration of colonization arguably captures the degree of involvement of the colonial power in the colony. More sustained investment and longer time horizons are related to the development of a more inclusive institutional framework (Olson, 1993). 


\section{Control variables}

When estimating the changing impact of colonial legacies on institutional development, I control for the effects of per capita income as a main determinant of institutional quality (Feenstra et al., 2015). Other countryspecific factors that have been shown to influence (institutional) development include geographical characteristics and the precolonial social environment. Geographical characteristics included are absolute latitude, distance to seacoasts, malaria risk, suitability for agriculture and roughness of the landscape. All these data are from Ashraf and Galor (2013) and Michalopoulos and Papaioannou (2013). From the same sources, I also include information about the precolonial social environment, specifically the spread of Islam and precolonial institutional development, measured by the extent of hierarchical organization transcending the village level. The idea is that hierarchical organization requires more institutionalization, as such organization relies on rules and regulations that apply across time and space. Places that were part of larger, hierarchically organized entities are thus deemed to have been more institutionally developed and less spatially fractionalized than countries consisting of loosely connected village communities. The social infrastructure is in place to build effective institutions after independence. The underlying data come from the Ethnographic Atlas (Murdock, 1967). Since all data from Michalopoulos and Papaioannou (2013) are at the regional level, I have aggregated them using the regional population (also from Michalopoulos and Papaioannou, 2013) as weights to obtain national data. Summary statistics are presented in Table 2 and a correlation matrix in Table 3.

\section{Results}

I start out by estimating the relations between the various dimensions of colonial legacy and institutional quality or per capita income after independence, repeating this for each year of independence. Subsequently, I plot the estimated coefficients and their confidence intervals against country age. Figure 1 reports the results graphically.

The upper row presents results for institutional quality. Two things stand out. First, two dimensions of colonial legacy, British origin and settlers, contribute to institutional quality shortly after independence. Duration starts having a significant impact only after 10 years. All effects have the expected signs and are in this respect in line with results previously found in the literature (Acemoglu et al., 2001; Bertocchi and Canova, 2002; Grier, 1997, 1999; La Porta et al., 2008). Second, the effects of colonial legacy seem significantly unstable over time, with the overall trends moving towards zero. Although it is not a completely smooth trajectory, the rate of decline of the impact of British origin and settlers is such that their effects on expropriation risk lose significance after one to three 
Table 2. Summary statistics

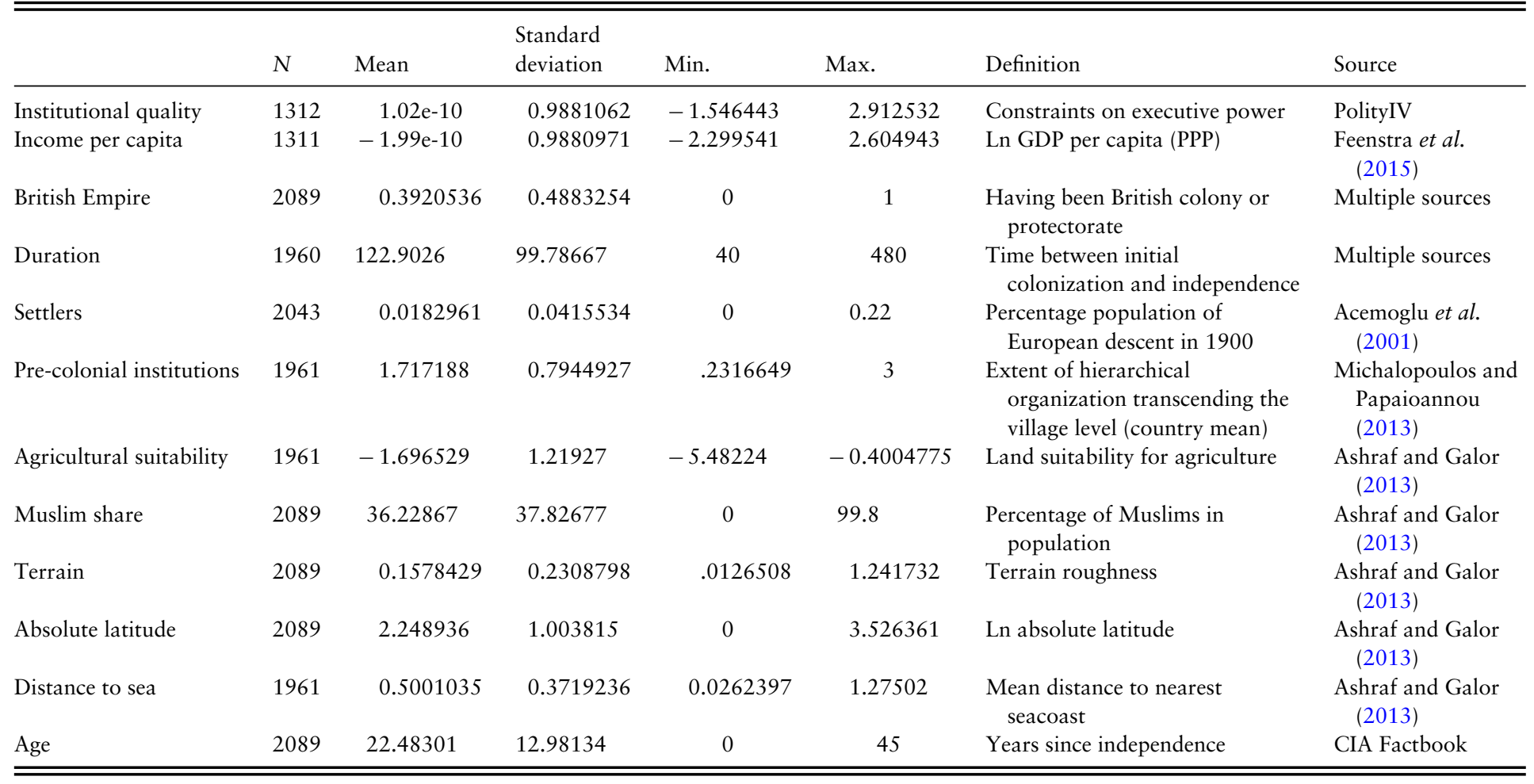

Notes: The full dataset is available from the author on request. 
Table 3. Correlation matrix

\begin{tabular}{|c|c|c|c|c|c|c|c|c|c|c|c|c|c|}
\hline & $\begin{array}{l}\text { Institutional } \\
\text { quality }\end{array}$ & $\begin{array}{l}\text { Income per } \\
\text { capita }(\ln )\end{array}$ & British & Duration & Settlers & $\begin{array}{l}\text { Precolonial } \\
\text { institutions }\end{array}$ & $\begin{array}{l}\text { Agricultural } \\
\text { suitability }\end{array}$ & Islam & Terrain & Latitude & $\begin{array}{l}\text { Distance } \\
\text { to coast }\end{array}$ & Malaria & Age \\
\hline $\begin{array}{c}\text { Institutional } \\
\text { quality }\end{array}$ & 1 & & & & & & & & & & & & \\
\hline $\begin{array}{l}\text { Income per } \\
\text { capita }(\ln )\end{array}$ & 0.260 & 1 & & & & & & & & & & & \\
\hline British & $0.376^{*}$ & 0.137 & 1 & & & & & & & & & & \\
\hline Duration & $0.471^{* *}$ & 0.219 & -0.0981 & 1 & & & & & & & & & \\
\hline Settlers & $0.453^{* *}$ & $0.578^{* * *}$ & 0.0570 & $0.446^{* *}$ & 1 & & & & & & & & \\
\hline $\begin{array}{l}\text { Precolonial } \\
\text { institu- } \\
\text { tions }\end{array}$ & 0.141 & 0.0385 & 0.0668 & -0.0646 & 0.218 & 1 & & & & & & & \\
\hline $\begin{array}{l}\text { Agricultural } \\
\text { suitability }\end{array}$ & -0.110 & -0.255 & 0.167 & 0.119 & -0.00619 & -0.186 & 1 & & & & & & \\
\hline Islam & -0.131 & 0.0680 & -0.215 & -0.145 & -0.120 & 0.198 & $-0.543^{* * *}$ & 1 & & & & & \\
\hline Terrain & -0.0817 & -0.132 & -0.0998 & $0.353^{*}$ & 0.184 & $0.330^{*}$ & 0.198 & -0.0478 & 1 & & & & \\
\hline Latitude & 0.271 & 0.0950 & 0.0860 & 0.151 & 0.209 & $0.504^{* * *}$ & -0.168 & $0.429^{* *}$ & 0.00868 & 1 & & & \\
\hline $\begin{array}{l}\text { Distance to } \\
\text { coast }\end{array}$ & -0.271 & -0.295 & -0.0924 & $-0.337^{*}$ & 0.0482 & -0.0779 & -0.0624 & -0.134 & -0.0598 & -0.209 & 1 & & \\
\hline Malaria & $-0.359^{*}$ & $-0.495^{* *}$ & -0.187 & -0.0277 & $-0.388^{* *}$ & $-0.638^{* * *}$ & 0.280 & -0.200 & -0.256 & $-0.540^{* * *}$ & 0.195 & 1 & \\
\hline Age & -0.202 & -0.0369 & 0.161 & -0.290 & -0.174 & 0.245 & $-0.403^{* *}$ & 0.263 & -0.190 & 0.134 & -0.0531 & $-0.396^{* *}$ & 1 \\
\hline
\end{tabular}

Notes: ${ }^{* * *} p<0.01,{ }^{* *} p<0.05,{ }^{*} p<0.1$. VIF scores are all $<3.11$. 
Figure 1. (Colour online) Evolution of Colonial Legacy Impact

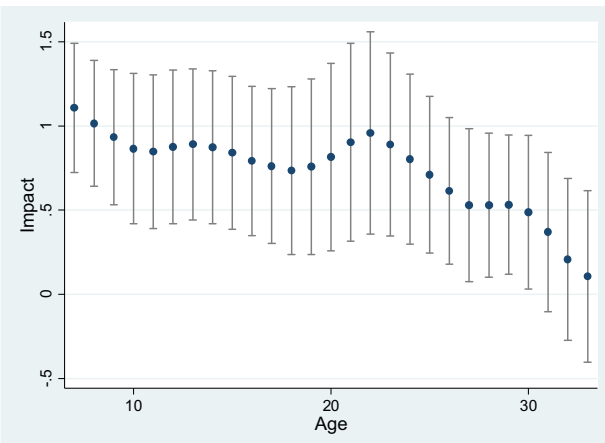

Impact of British Empire on institutional quality

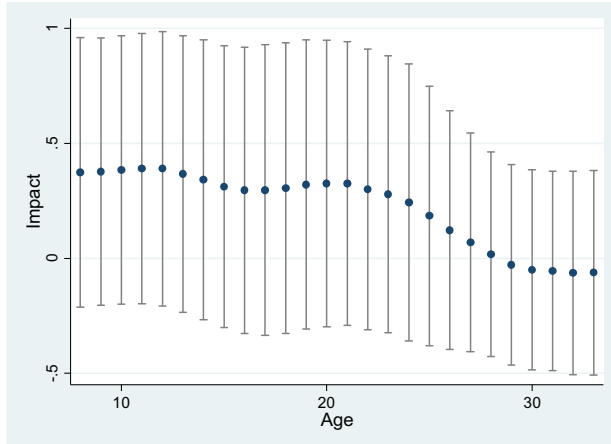

Impact of British origin on income per capita

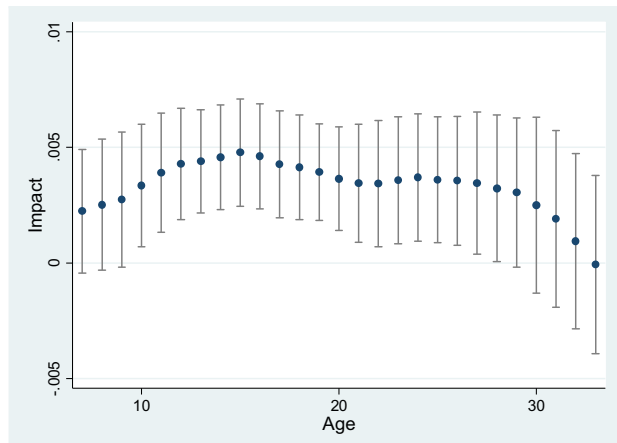

Impact of duration on institutional quality

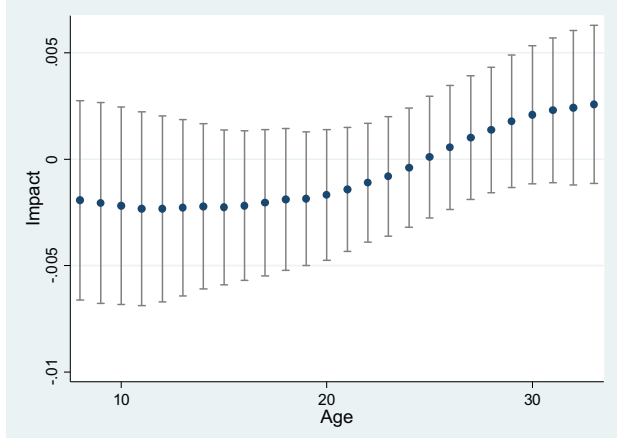

Impact of duration on income per capita

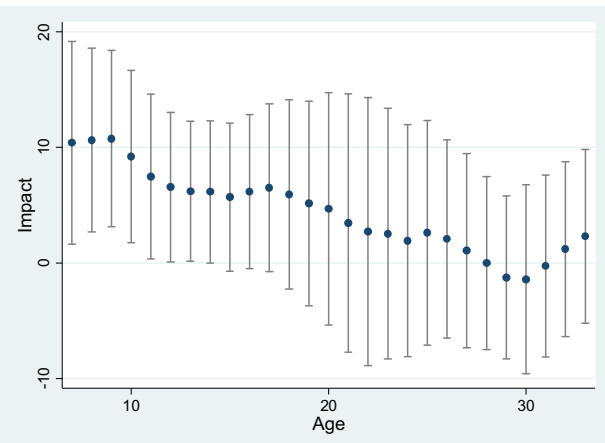

Impact of settlers on institutional quality

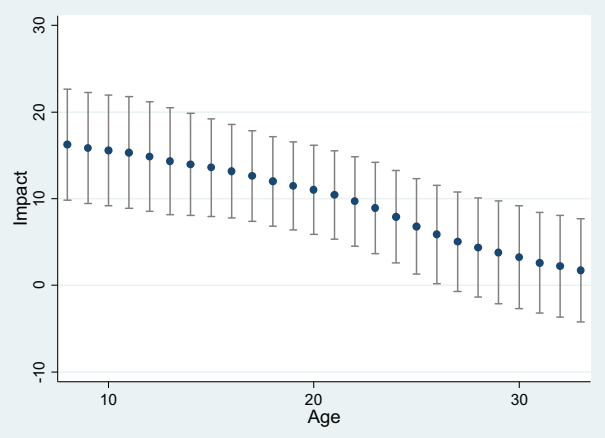

Impact of settlers on income per capita

Notes: These figures present the relation between the institutional quality impacts (upper row) and per capita income impacts (bottom row) of various dimensions of colonial legacy and country age. Institutional quality impacts are based on underlying regressions capturing the effect of colonial legacy on institutional quality (expropriation risk), controlled for latitude, pre-colonial institutions, roughness of landscape, Muslim population share, distance to seacoast, the distribution of arable land, and year. The period covered is restricted to ensure constant samples. Depicted are regression coefficients and $90 \%$ confidence intervals. Negative slopes indicate that the impact of colonial legacy on institutions is diminishing when countries move away from their independence date. 
decades of independence. For duration, the initial increase in impact is reversed, so that duration also stops having a significant impact after three decades. This is a first indication that hypotheses $1 \mathrm{a}-1 \mathrm{c}$ should be rejected.

If the effect on institutional quality is disappearing, what is happening to the income effect? Since it takes some time for the initial positive effects of the colonial legacy variables on institutional quality to disappear, one would expect any impact on incomes to be more persistent than the legacy effects on institutions. The bottom row of Figure 1 shows the evolution of the colonial legacy effect on income over time. In contrast to our second set of hypotheses, I find no evidence of any effect of two dimensions of colonial legacy on income at all. Neither having been subject to British rule nor duration of colonial rule has a significant effect on income at any point in time after independence. The only dimension that enters significantly is the mode of colonialism, proxied by the proportion of European settlers. For this variable, there is a clear downward trend in impact such that it loses significance after about three decades. All together, these results suggest that the colonial legacy effects on institutions have all but disappeared by now, and that initial effects on income - if any - have disappeared as well.

\section{Panel analysis}

The illustrative evidence is confirmed by a panel analysis, more efficiently exploiting all available information. Results are portrayed in Table 4. All models include year-fixed effects and random country effects. Breusch-Pagan Lagrange Multiplier (ML) tests and Hausman tests confirm that there is significant variation between countries and that the random country effects model is consistent. The first four columns present the results for institutional quality, for each dimension of colonial legacy separately (columns 1-3), and for all of them together (column 4).

Throughout the specifications shown in columns 1-4, British colonial rule enters as significantly positive, while the interaction term between country age and British colonial rule is significantly negative. This suggests that the initial effect of this dimension of colonial rule decreases after independence. The same applies to the impacts of duration of colonialism and of the legacy variable. The proportion of populations descending from colonial settlers is the exception. There are no indications that the impact of settlers changes with age, nor is there an indication of an initial effect.

Columns 5-8 repeat this exercise for per capita income as dependent variable. Again, results confirm the illustrative evidence presented thus far. There is no evidence of changes in the impacts on per capita income of having been part of the British Empire, or of the duration of colonial rule. The effect of the proportion of settlers, however, declines significantly with age.

To assess the degree of persistence of colonial legacy effects, I plot the marginal effects of the colonial legacy variables on institutional quality (Figure 2, 
Table 4. The Declining Effect of Colonial Legacy: Panel Analysis

\begin{tabular}{|c|c|c|c|c|c|c|c|c|}
\hline & \multicolumn{4}{|c|}{ Institutional quality } & \multicolumn{4}{|c|}{ Income per capita } \\
\hline & (1) & (2) & (3) & (4) & (5) & (6) & (7) & (8) \\
\hline Age & $\begin{array}{c}-0.00334 \\
(0.0209)\end{array}$ & $\begin{array}{r}-0.00462 \\
(0.0211)\end{array}$ & $\begin{array}{c}0.0218 \\
(0.0248)\end{array}$ & $\begin{array}{c}0.0371 \\
(0.0256)\end{array}$ & $\begin{array}{c}0.00330 \\
(0.0244)\end{array}$ & $\begin{array}{c}0.0110 \\
(0.0209)\end{array}$ & $\begin{array}{c}0.00446 \\
(0.0275)\end{array}$ & $\begin{array}{c}0.00156 \\
(0.0194)\end{array}$ \\
\hline British & $\begin{array}{c}0.766^{* *} \\
(0.309)\end{array}$ & & & $\begin{array}{l}0.904^{* * *} \\
(0.298)\end{array}$ & $\begin{array}{c}0.411 \\
(0.419)\end{array}$ & & & $\begin{array}{c}0.270 \\
(0.394)\end{array}$ \\
\hline British * age & $\begin{array}{r}-0.0180^{* *} \\
(0.00893)\end{array}$ & & & $\begin{array}{r}-0.0214^{* *} \\
(0.00875)\end{array}$ & $\begin{array}{r}-0.0101 \\
(0.0129)\end{array}$ & & & $\begin{array}{c}-0.00552 \\
(0.0138)\end{array}$ \\
\hline Settlers & & $\begin{array}{c}6.604 \\
(6.001)\end{array}$ & & $\begin{array}{r}-0.622 \\
(5.297)\end{array}$ & & $\begin{array}{c}1.92^{* * *} \\
(2.389)\end{array}$ & & $\begin{array}{l}13.46^{* * *} \\
(3.186)\end{array}$ \\
\hline Settlers * age & & $\begin{array}{r}-0.0411 \\
(0.0841)\end{array}$ & & $\begin{array}{c}0.115 \\
(0.0859)\end{array}$ & & $\begin{array}{r}-0.130^{* *} \\
(0.0585)\end{array}$ & & $\begin{array}{c}-0.176^{*} \\
(0.0941)\end{array}$ \\
\hline Duration & & & $\begin{array}{c}0.00540^{* *} \\
(0.00243)\end{array}$ & $\begin{array}{l}0.00611^{* * *} \\
(0.00227)\end{array}$ & & & $\begin{array}{c}0.00107 \\
(0.00250)\end{array}$ & $\begin{array}{r}-0.00235 \\
(0.00235)\end{array}$ \\
\hline Duration * age & & & $\begin{array}{c}-0.000104^{*} \\
(6.03 \mathrm{e}-05)\end{array}$ & $\begin{array}{c}-0.000140^{* *} \\
(6.83 \mathrm{e}-05)\end{array}$ & & & $\begin{array}{c}1.12 \mathrm{e}-05 \\
(5.45 \mathrm{e}-05)\end{array}$ & $\begin{array}{c}5.29 \mathrm{e}-05 \\
(5.90 \mathrm{e}-05)\end{array}$ \\
\hline Income per capita & $\begin{array}{c}0.0771 \\
(0.115)\end{array}$ & $\begin{array}{c}0.0665 \\
(0.132)\end{array}$ & $\begin{array}{c}0.0872 \\
(0.135)\end{array}$ & $\begin{array}{r}0.0555 \\
(0.121)\end{array}$ & & & & \\
\hline Latitude & $\begin{array}{c}0.145 \\
(0.143)\end{array}$ & $\begin{array}{c}0.135 \\
(0.156)\end{array}$ & $\begin{array}{c}0.148 \\
(0.153)\end{array}$ & $\begin{array}{c}0.124 \\
(0.133)\end{array}$ & $\begin{array}{r}-0.307 \\
(0.193)\end{array}$ & $\begin{array}{r}-0.326^{*} \\
(0.170)\end{array}$ & $\begin{array}{r}-0.306 \\
(0.187)\end{array}$ & $\begin{array}{r}-0.336^{*} \\
(0.174)\end{array}$ \\
\hline Terrain & $\begin{array}{r}-1.327 \\
(1.686)\end{array}$ & $\begin{array}{r}-0.659 \\
(2.104)\end{array}$ & $\begin{array}{r}-0.638 \\
(1.678)\end{array}$ & $\begin{array}{r}-0.619 \\
(1.727)\end{array}$ & $\begin{array}{c}-4.349^{* *} \\
(1.692)\end{array}$ & $\begin{array}{c}-3.461^{* * *} \\
(1.263)\end{array}$ & $\begin{array}{c}-4.157^{* *} \\
(1.832)\end{array}$ & $\begin{array}{c}-3.850^{* * *} \\
(1.270)\end{array}$ \\
\hline
\end{tabular}


Table 4. Continued

\begin{tabular}{|c|c|c|c|c|c|c|c|c|}
\hline & \multicolumn{4}{|c|}{ Institutional quality } & \multicolumn{4}{|c|}{ Income per capita } \\
\hline & (1) & (2) & (3) & (4) & (5) & (6) & (7) & (8) \\
\hline Malaria & $\begin{array}{c}0.0480 \\
(0.432)\end{array}$ & $\begin{array}{c}0.226 \\
(0.472)\end{array}$ & $\begin{array}{r}-0.114 \\
(0.443)\end{array}$ & $\begin{array}{c}0.124 \\
(0.426)\end{array}$ & $\begin{array}{c}-1.621^{* * *} \\
(0.414)\end{array}$ & $\begin{array}{c}-1.191^{* * *} \\
(0.305)\end{array}$ & $\begin{array}{c}-1.715^{* * * *} \\
(0.376)\end{array}$ & $\begin{array}{c}-1.043^{* * *} \\
(0.317)\end{array}$ \\
\hline Distance to coast & $\begin{array}{c}-0.390 \\
(0.271)\end{array}$ & $\begin{array}{r}-0.475 \\
(0.290)\end{array}$ & $\begin{array}{r}-0.213 \\
(0.272)\end{array}$ & $\begin{array}{c}-0.245 \\
(0.304)\end{array}$ & $\begin{array}{c}-0.829^{* *} \\
(0.324)\end{array}$ & $\begin{array}{c}-0.932^{* * *} \\
(0.295)\end{array}$ & $\begin{array}{c}-0.769^{* *} \\
(0.316)\end{array}$ & $\begin{array}{c}-1.020^{* * *} \\
(0.314)\end{array}$ \\
\hline Precolonial institutions & $\begin{array}{c}-0.00840 \\
(0.130)\end{array}$ & $\begin{array}{c}-0.0559 \\
(0.137)\end{array}$ & $\begin{array}{c}-0.0258 \\
(0.129)\end{array}$ & $\begin{array}{c}-0.00696 \\
(0.117)\end{array}$ & $\begin{array}{c}0.0518 \\
(0.154)\end{array}$ & $\begin{array}{c}0.00781 \\
(0.134)\end{array}$ & $\begin{array}{c}0.0450 \\
(0.153)\end{array}$ & $\begin{array}{c}0.0237 \\
(0.141)\end{array}$ \\
\hline Agricultural suitability & $\begin{array}{c}-0.220^{* *} \\
(0.104)\end{array}$ & $\begin{array}{c}-0.181 \\
(0.121)\end{array}$ & $\begin{array}{r}-0.229^{*} \\
(0.117)\end{array}$ & $\begin{array}{c}-0.273^{* *} \\
(0.115)\end{array}$ & $\begin{array}{c}-0.256^{* *} \\
(0.101)\end{array}$ & $\begin{array}{r}-0.229^{* *} \\
(0.0937)\end{array}$ & $\begin{array}{c}-0.257^{* *} \\
(0.108)\end{array}$ & $\begin{array}{r}-0.231^{* *} \\
(0.0901)\end{array}$ \\
\hline Islam & $\begin{array}{r}-0.00610 \\
(0.00500)\end{array}$ & $\begin{array}{r}-0.00669 \\
(0.00542)\end{array}$ & $\begin{array}{r}-0.00857^{*} \\
(0.00477)\end{array}$ & $\begin{array}{c}-0.00612 \\
(0.00428)\end{array}$ & $\begin{array}{r}-0.00418 \\
(0.00399)\end{array}$ & $\begin{array}{r}-0.00330 \\
(0.00280)\end{array}$ & $\begin{array}{r}-0.00542 \\
(0.00351)\end{array}$ & $\begin{array}{r}-0.00223 \\
(0.00334)\end{array}$ \\
\hline Constant & $\begin{array}{r}-0.544 \\
(0.639)\end{array}$ & $\begin{array}{r}-0.439 \\
(0.703)\end{array}$ & $\begin{array}{r}-0.720 \\
(0.737)\end{array}$ & $\begin{array}{r}-1.272^{*} \\
(0.757)\end{array}$ & $\begin{array}{r}1.665^{*} \\
(0.891)\end{array}$ & $\begin{array}{c}1.376^{*} \\
(0.726)\end{array}$ & $\begin{array}{c}1.717^{* *} \\
(0.820)\end{array}$ & $\begin{array}{c}1.364 \\
(0.860)\end{array}$ \\
\hline Obs. & 1,252 & 1,252 & 1,219 & 1,219 & 1,252 & 1,252 & 1,219 & 1,219 \\
\hline Number of countries & 38 & 38 & 37 & 37 & 38 & 38 & 37 & 37 \\
\hline
\end{tabular}

Notes: Table presents the evolution of the impact of colonial legacy on institutional quality and income. Institutional quality reflects the risk of expropriation by the state. Income per capita and latitude (absolute) are included as natural logs. All models are generalized least squares including year-fixed effects and random country effects. Hausman tests show that for all models random effects are acceptable, while Breusch-Pagan Lagrange Multiplier tests show that variance in country effects is significant. Only ages are included which at least 30 countries have reached. Results show that belonging to the British Empire and the duration of colonial rule have an initial effect on institutional quality, but that this effect is decreasing over age. The percentage of settlers has no initial effect, but there are inconsistent indications that an effect emerges over time. For income, only the percentage of settlers-dimension of colonial legacy has an initial effect, but this effect is declining over age. Robust standard errors (clustered at country level) in parentheses. ${ }^{* * *} p<0.01,{ }^{* *} p<0.05,{ }^{*} p<0.1$ 
Figure 2. (Colour online) Marginal effects of colonial legacy

\section{Panel A Institutional quality effects}
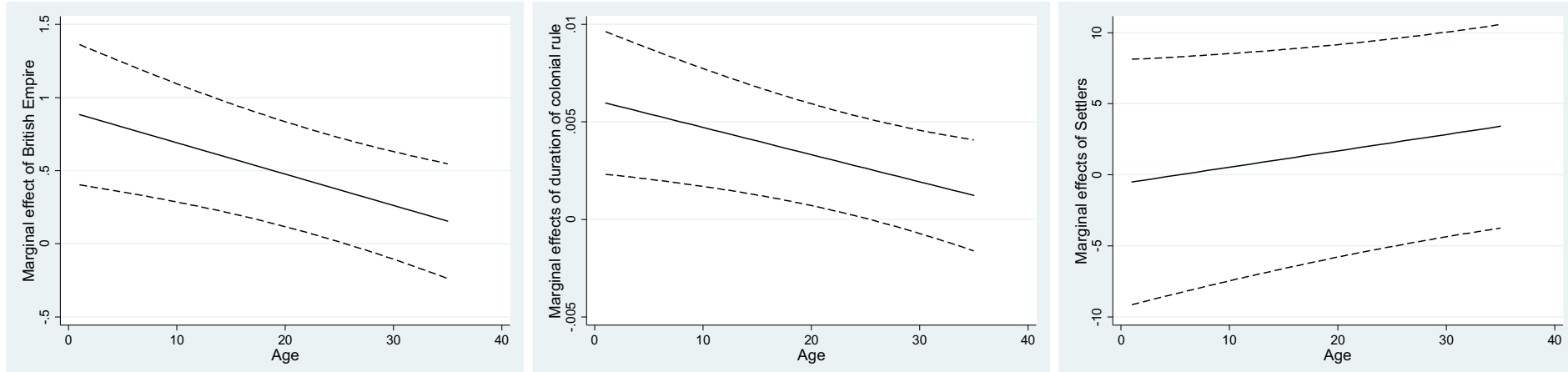

\section{Panel B Per Capita Income effects}
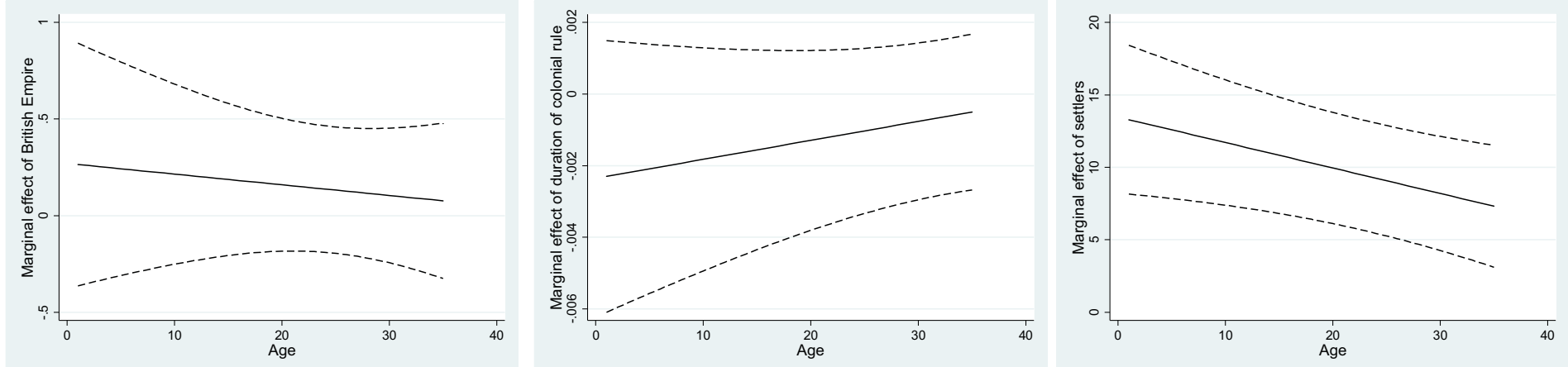

Notes: These figures present the evolution of marginal effects of various dimensions of colonial legacy over the age range under study. Solid lines represent marginal effects. Dashed lines present $90 \%$ confidence intervals. Results are based on Models 4 (Panel A) and 8 (Panel B) of Table 4. Panel A shows a disappearing effect of British Empire and duration of colonial rule on institutional quality. The mode of colonization, proxied by the proportion of settlers, has no significant effect on institutional quality for the entire age range. Panel B shows a declining effect of the proportion of settlers on per capita income, though it remains significant throughout the entire age range. British Empire and duration have no significant income effect for any observed country age. 
Panel A) and per capita income (Figure 2, Panel B) across the observed age range with $90 \%$ confidence intervals.

Results show that having been part of the British Empire and the duration of colonial rule have a significant impact on institutional quality in the period following independence. However, this impact declines with age, until it loses significance in the third decade of independence. The proportion of settlers on institutions is never significant in the entire age range.

For income, neither having been part of the British Empire nor duration of colonial rule has a significant effect for any relevant age. These results confirm the repeated regression results presented before. Likewise, Panel B shows that the positive effect of the proportion of settlers decreases with age. In contrast to the repeated regression results, although Figure 3, Panel B, reveals that the proportion of settlers continues to be a significant predictor throughout the entire age range.

All in all, these results suggest that any effects of colonial legacy that were present after independence are declining or even disappearing with country age. This indicates that we are leaving behind us the times in which a colonial institutional legacy existed. Similarly, institutions inherited from colonial times appear to have no or diminishing effects on per capita incomes. Increasingly, both institutional quality and income in Africa are determined primarily by factors other than colonial legacy. This result has significant policy implications: when countries are less held back by their colonial background, new possibilities open up for autonomous institutional development and economic growth. Theoretically, the results of this analysis suggest that arguments about pathdependence and institutional persistence (Acemoglu et al., 2001) following colonialism are vastly overblown. The exposure of African societies to European colonialism has not set countries on an institutional trajectory from which it is hard to change course. Colonialism has left its mark on Africa, but time is rapidly healing the colonial wounds.

\section{If not colonial legacies, what else?}

Results so far indicate that the impact of colonial legacies is declining. This begs the question what is replacing it. One school of thought holds that geography determines institutional and economic development (Gallup et al., 1999; Sachs, 2003). This suggests that when the effect of colonial legacies wears off, countries return to their natural trajectory of institutional and economic development. Alternatively, various scholars have argued that precolonial institutions have an important effect on present-day institutions and incomes (Gennaioli and Rainer, 2007; Michalopoulos and Papaioannou, 2013; Nunn, 2008). As with geographical determinants, this argument suggests a gradual restoration of a long-run equilibrium after independence. Thus one may expect strong precolonial institutions to determine institutional quality increasingly after independence. However, a clash between precolonial and 
Figure 3. (Colour online) Marginal effects of deep determinants

\section{Panel A Institutional quality effects}
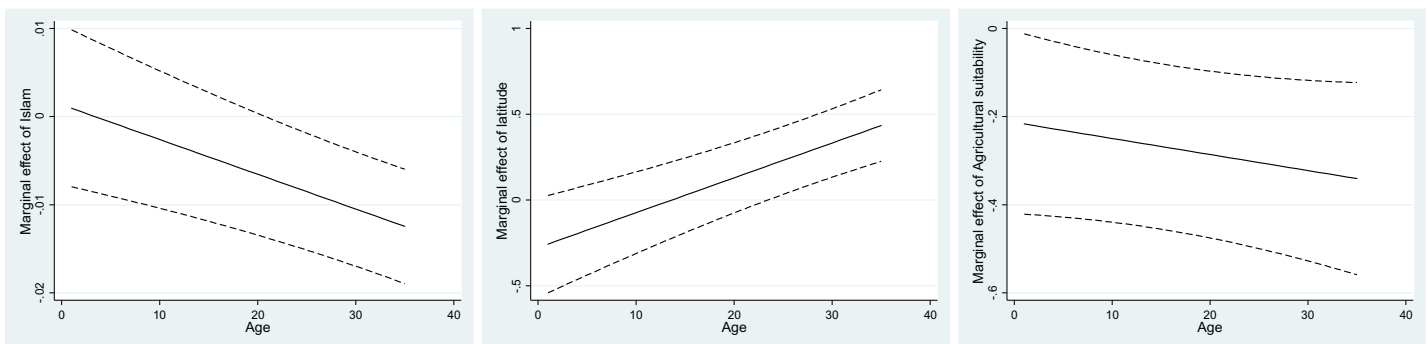

\section{Panel B Per Capita Income effects}
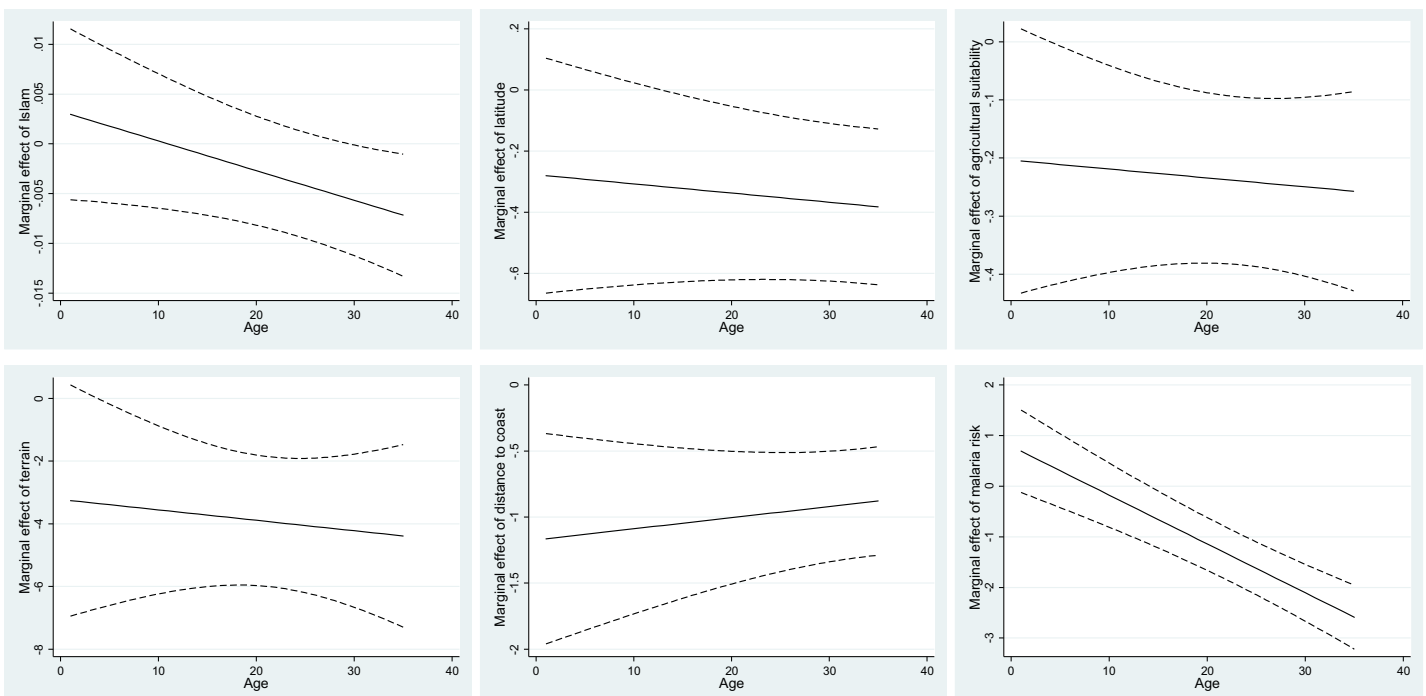

Notes: These figures present the evolution of marginal effects of various deep determinants over the age range under study. Solid lines represent marginal effects. Dashed lines present $90 \%$ confidence intervals. Results are based on Models 3 (Panel A) and 7 (Panel B) of Table 5. Panel A shows emerging effects of Islam and latitude on institutional quality. The negative effect of agricultural suitability appears to increase over time. Panel B indicates emerging effects of Islam, latitude, agricultural suitability, terrain, and malaria risk on per capita income. 
colonial institutions may also create conflicts that have a detrimental effect on institutional quality (Michalopoulos and Papaioannou, 2016). While both effects are plausible, the negative effect of strong precolonial institutions is more likely to play out in the period directly after independence. The positive effect, the restoration of a long-run equilibrium, is more likely to dominate in later periods.

To see whether these arguments are supported by data, I add interactions of age with the geographical variables to the analysis. These include interactions with absolute latitude, distance to sea coasts, land quality, malaria risk and the roughness of the terrain. Second, I add interactions of age with the variables capturing the social environment, i.e. precolonial institutional development (Michalopoulos and Papaioannou, 2013) and the share of Muslims in the population (Ashraf and Galor, 2013).

Table 5 presents the results. The first three models show what happens when interactions with deep determinants are added to the institutional quality results (columns 1-3). Column 1 adds interactions with measures of the social environment, column 2 adds geographic interactions, and column 3 adds both. Models 4-6 repeat this procedure with per capita income as the dependent variable.

As in the main analysis, results show that the initial institutional effects of British Empire and duration decrease over time. The effect of the proportion of settlers on institutional quality is not significant initially and does not change significantly with age. In contrast, with regard to per capita income, the proportion of settlers does appear to have an effect initially and this effect declines over time. The effects of the other two dimensions are neither significant initially nor does it change significantly with age.

The influence of some aspects of the social and geographical environment, notably latitude, terrain and Islam, appear to change with age. The interaction of Islam and age has a significant negative effect on institutional quality, while the interaction of latitude and age has a significant positive effect. With income per capita as a dependent variable, the effect of malaria risk also becomes significantly more negative over time. To assess the degree of increase in impact of these deep determinants, I again plot their marginal effects against age (Figure 3). Because of space limitations, Figure 3 presents only those geographical and historical variables that enter significantly at some point. Similar figures for the remaining variables are available on request.

Panel A shows the emerging effects of Islam and latitude, as well as an increasing effect of agricultural suitability on institutional quality. Panel B shows the similarly emerging effects of Islam, latitude, agricultural suitability, terrain, and malaria risk on per capita income. Together, this suggests that when moving further away from colonialism, social and environmental factors gradually replace the impact of colonial legacies. Such a restoration of a longterm equilibrium appears to be related to the loss of relevance of colonial legacies. 
Table 5. The Evolution of Colonial Legacy versus Deep Determinants

\begin{tabular}{|c|c|c|c|c|c|c|}
\hline & \multicolumn{3}{|c|}{ Institutional quality } & \multicolumn{3}{|c|}{ Income per capita } \\
\hline & $(1)$ & (2) & (3) & (4) & (5) & (6) \\
\hline Age & $\begin{array}{c}0.0372 \\
(0.0241)\end{array}$ & $\begin{array}{r}-0.0198 \\
(0.0334)\end{array}$ & $\begin{array}{c}-0.0111 \\
(0.0316)\end{array}$ & $\begin{array}{c}0.00226 \\
(0.0213)\end{array}$ & $\begin{array}{l}0.0990^{* * *} \\
(0.0315)\end{array}$ & $\begin{array}{l}0.1000^{* * *} \\
(0.0302)\end{array}$ \\
\hline British & $\begin{array}{l}1.030^{* * *} \\
(0.295)\end{array}$ & $\begin{array}{l}0.905^{* * *} \\
(0.293)\end{array}$ & $\begin{array}{l}1.065^{* * *} \\
(0.275)\end{array}$ & $\begin{array}{c}0.427 \\
(0.362)\end{array}$ & $\begin{array}{c}0.402 \\
(0.374)\end{array}$ & $\begin{array}{c}0.500 \\
(0.374)\end{array}$ \\
\hline British * age & $\begin{array}{c}-0.0280^{* * *} \\
(0.00857)\end{array}$ & $\begin{array}{r}-0.0217^{* *} \\
(0.00866)\end{array}$ & $\begin{array}{c}-0.0300^{* * *} \\
(0.00734)\end{array}$ & $\begin{array}{c}-0.00902 \\
(0.0138)\end{array}$ & $\begin{array}{r}-0.0120 \\
(0.0124)\end{array}$ & $\begin{array}{r}-0.0174 \\
(0.0112)\end{array}$ \\
\hline Settlers & $\begin{array}{c}0.371 \\
(5.415)\end{array}$ & $\begin{array}{c}0.154 \\
(6.097)\end{array}$ & $\begin{array}{c}2.530 \\
(6.157)\end{array}$ & $\begin{array}{l}18.28^{* * *} \\
(3.287)\end{array}$ & $\begin{array}{c}21.41^{* * *} \\
(4.292)\end{array}$ & $\begin{array}{c}22.20^{* * *} \\
(3.866)\end{array}$ \\
\hline Settlers * age & $\begin{array}{c}0.0771 \\
(0.0941)\end{array}$ & $\begin{array}{r}0.0675 \\
(0.146)\end{array}$ & $\begin{array}{r}-0.0220 \\
(0.142)\end{array}$ & $\begin{array}{r}-0.239^{* *} \\
(0.0994)\end{array}$ & $\begin{array}{c}-0.602^{* * *} \\
(0.157)\end{array}$ & $\begin{array}{c}-0.642^{* * *} \\
(0.142)\end{array}$ \\
\hline Duration & $\begin{array}{c}0.00581^{* * *} \\
(0.00199)\end{array}$ & $\begin{array}{l}0.00572^{* * *} \\
(0.00210)\end{array}$ & $\begin{array}{l}0.00526^{* * *} \\
(0.00178)\end{array}$ & $\begin{array}{r}-0.00363 \\
(0.00225)\end{array}$ & $\begin{array}{r}-0.00435^{*} \\
(0.00241)\end{array}$ & $\begin{array}{c}-0.00449^{* *} \\
(0.00226)\end{array}$ \\
\hline Duration * age & $\begin{array}{c}-0.000126^{* *} \\
(6.07 \mathrm{e}-05)\end{array}$ & $\begin{array}{c}-0.000119^{*} \\
(7.03 \mathrm{e}-05)\end{array}$ & $\begin{array}{r}-0.000101 \\
(6.25 \mathrm{e}-05)\end{array}$ & $\begin{array}{c}7.29 \mathrm{e}-05 \\
(5.58 \mathrm{e}-05)\end{array}$ & $\begin{array}{l}0.000163^{* *} \\
(6.68 \mathrm{e}-05)\end{array}$ & $\begin{array}{l}0.000169^{* * *} \\
(5.74 \mathrm{e}-05)\end{array}$ \\
\hline $\begin{array}{l}\text { Precolonial } \\
\text { institutions }\end{array}$ & $\begin{array}{r}-0.0961 \\
(0.152)\end{array}$ & $\begin{array}{c}-0.00708 \\
(0.117)\end{array}$ & $\begin{array}{c}0.165 \\
(0.174)\end{array}$ & $\begin{array}{c}-0.0592 \\
(0.188)\end{array}$ & $\begin{array}{c}0.0228 \\
(0.141)\end{array}$ & $\begin{array}{c}0.113 \\
(0.239)\end{array}$ \\
\hline $\begin{array}{l}\text { Precolonial * } \\
\text { age }\end{array}$ & $\begin{array}{c}0.00471 \\
(0.00466)\end{array}$ & & $\begin{array}{r}-0.00902 \\
(0.00678)\end{array}$ & $\begin{array}{c}0.00852 \\
(0.00581)\end{array}$ & & $\begin{array}{r}-0.00475 \\
(0.00781)\end{array}$ \\
\hline Islam & $\begin{array}{r}-0.00176 \\
(0.00491)\end{array}$ & $\begin{array}{r}-0.00607 \\
(0.00431)\end{array}$ & $\begin{array}{c}0.00134 \\
(0.00550)\end{array}$ & $\begin{array}{c}0.000145 \\
(0.00482)\end{array}$ & $\begin{array}{r}-0.00245 \\
(0.00337)\end{array}$ & $\begin{array}{c}0.00326 \\
(0.00536)\end{array}$ \\
\hline Islam * age & $\begin{array}{c}-0.000231^{* *} \\
(9.37 \mathrm{e}-05)\end{array}$ & & $\begin{array}{c}-0.000394^{* * *} \\
(0.000119)\end{array}$ & $\begin{array}{r}-0.000137 \\
(0.000143)\end{array}$ & & $\begin{array}{r}-0.000298^{*} \\
(0.000175)\end{array}$ \\
\hline Latitude & $\begin{array}{c}0.116 \\
(0.130)\end{array}$ & $\begin{array}{r}-0.103 \\
(0.166)\end{array}$ & $\begin{array}{r}-0.277 \\
(0.176)\end{array}$ & $\begin{array}{r}-0.199 \\
(0.171)\end{array}$ & $\begin{array}{r}-0.168 \\
(0.212)\end{array}$ & $\begin{array}{r}-0.277 \\
(0.238)\end{array}$ \\
\hline Latitude * age & & $\begin{array}{c}0.0122^{* * *} \\
(0.00442)\end{array}$ & $\begin{array}{c}0.0203^{* * *} \\
(0.00484)\end{array}$ & & $\begin{array}{c}-0.00875^{* *} \\
(0.00354)\end{array}$ & $\begin{array}{r}-0.00300 \\
(0.00519)\end{array}$ \\
\hline Agricultural suitability & $\begin{array}{c}-0.278^{* *} \\
(0.114)\end{array}$ & $\begin{array}{c}-0.311^{* * *} \\
(0.118)\end{array}$ & $\begin{array}{r}-0.213^{*} \\
(0.126)\end{array}$ & $\begin{array}{c}-0.283^{* * *} \\
(0.102)\end{array}$ & $\begin{array}{c}-0.289^{* *} \\
(0.126)\end{array}$ & $\begin{array}{r}-0.204 \\
(0.142)\end{array}$ \\
\hline
\end{tabular}


Table 5. Continued

\begin{tabular}{|c|c|c|c|c|c|c|}
\hline & \multicolumn{3}{|c|}{ Institutional quality } & \multicolumn{3}{|c|}{ Income per capita } \\
\hline & (1) & (2) & (3) & (4) & (5) & (6) \\
\hline Agric. suit.* age & & $\begin{array}{c}0.00221 \\
(0.00321)\end{array}$ & $\begin{array}{c}-0.00365 \\
(0.00345)\end{array}$ & & $\begin{array}{c}0.00292 \\
(0.00372)\end{array}$ & $\begin{array}{r}-0.00153 \\
(0.00479)\end{array}$ \\
\hline Terrain & $\begin{array}{c}-0.721 \\
(1.712)\end{array}$ & $\begin{array}{r}-2.668 \\
(1.970)\end{array}$ & $\begin{array}{r}-3.585 \\
(2.430)\end{array}$ & $\begin{array}{r}-2.726^{*} \\
(1.469)\end{array}$ & $\begin{array}{c}-2.925 \\
(1.958)\end{array}$ & $\begin{array}{r}-3.225 \\
(2.318)\end{array}$ \\
\hline Terrain * age & & $\begin{array}{c}0.111^{*} \\
(0.0597)\end{array}$ & $\begin{array}{c}0.145^{*} \\
(0.0795)\end{array}$ & & $\begin{array}{r}-0.0485 \\
(0.0632)\end{array}$ & $\begin{array}{r}-0.0332 \\
(0.0911)\end{array}$ \\
\hline Malaria & $\begin{array}{c}0.0941 \\
(0.424)\end{array}$ & $\begin{array}{r}-0.139 \\
(0.551)\end{array}$ & $\begin{array}{r}-0.0157 \\
(0.578)\end{array}$ & & $\begin{array}{c}0.746 \\
(0.549)\end{array}$ & $\begin{array}{c}0.788 \\
(0.509)\end{array}$ \\
\hline Malaria * age & & $\begin{array}{c}0.0148 \\
(0.0205)\end{array}$ & $\begin{array}{c}0.00464 \\
(0.0192)\end{array}$ & & $\begin{array}{c}-0.0941^{* * *} \\
(0.0206)\end{array}$ & $\begin{array}{c}-0.0964^{* * *} \\
(0.0178)\end{array}$ \\
\hline Distance to coast & $\begin{array}{c}-0.274 \\
(0.293)\end{array}$ & $\begin{array}{r}-0.449 \\
(0.387)\end{array}$ & $\begin{array}{c}-0.416 \\
(0.394)\end{array}$ & $\begin{array}{c}-1.271^{* * *} \\
(0.371)\end{array}$ & $\begin{array}{c}-1.260^{* * *} \\
(0.483)\end{array}$ & $\begin{array}{c}-1.172^{* *} \\
(0.495)\end{array}$ \\
\hline Distance to coast ${ }^{*}$ age & & $\begin{array}{l}0.0114 \\
(0.00931)\end{array}$ & $\begin{array}{c}0.00578 \\
(0.00949)\end{array}$ & & $\begin{array}{c}0.0134 \\
(0.0132)\end{array}$ & $\begin{array}{c}0.00840 \\
(0.0126)\end{array}$ \\
\hline Income per capita & $\begin{array}{c}0.0305 \\
(0.116)\end{array}$ & $\begin{array}{c}0.0715 \\
(0.144)\end{array}$ & $\begin{array}{l}0.00856 \\
(0.135)\end{array}$ & & & \\
\hline Constant & $\begin{array}{c}-1.433^{* *} \\
(0.729)\end{array}$ & $\begin{array}{c}-0.193 \\
(0.836)\end{array}$ & $\begin{array}{c}-0.422 \\
(0.778)\end{array}$ & $\begin{array}{c}0.194 \\
(0.695)\end{array}$ & $\begin{array}{c}0.466 \\
(1.065)\end{array}$ & $\begin{array}{c}0.269 \\
(1.089)\end{array}$ \\
\hline Obs. & 1,219 & 1,219 & 1,219 & 1,219 & 1,219 & 1,219 \\
\hline Number of countries & 37 & 37 & 37 & 37 & 37 & 37 \\
\hline
\end{tabular}

Notes: Table presents the evolution of the impact of colonial legacy and deep determinants on institutional quality and income. Institutional quality reflects the risk of expropriation by the state. Income per capita and latitude (absolute) are included as natural logs. All models are generalized least squares including year-fixed effects and random country effects. Hausman tests show that for all models random effects are acceptable, while Breusch-Pagan Lagrange Multiplier tests show that variance in country effects is significant. Results show that the institutional quality effects of belonging to the British Empire and of the duration of colonial rule are significantly declining after independence. The impacts of latitude, Islam (and in some models terrain) on institutional quality are changing in the direction of their effect predicted in the literature as well. This tentatively suggests a restoration of an equilibrium determined by the pre-colonial social and natural environment. For per capita income, only the settlers-dimension of colonial legacy appears to have an initial effect, but this effect is declining over age. Effects of malaria risk, latitude and Islam appear to be changing over age as well. Robust standard errors (clustered at country level) in parentheses. ${ }^{* * *} p<.01$, ${ }^{* *} p<.05,{ }^{*} p<.1$ 
These results fit in the general story developed so far. It appears that colonialism has not set countries on different institutional or development paths. Rather, colonization caused a substantial temporary shock to institutional development, of which the impact continues to be felt decades after independence, but certainly not forever. The trajectory of institutional and economic development introduced during colonialism is not persistent. Societies seem to gradually pick up where they left off before European colonizers arrived.

\section{Robustness checks}

To what extent are the results presented thus far dependent on the specification of the models and choice of indicators? Figures 4 and 5 address this question, presenting the results of a series of robustness checks for effects of the British Empire dimension, the duration dimension and the settlers dimension of colonial legacy on institutional quality (Figure 4) and per capita income (Figure 5). In each figure, the upper panel presents marginal effects with age on institutional quality, while the lower panel presents marginal effects on economic performance indicators.

Two main concerns may be raised about the case put forward in this paper. First, the results may depend on the countries and periods covered in the sample. Second, the results may depend on the particular choice of institutional and economic performance indicators. To address these concerns, each row presents (1) the marginal effects of an analysis focusing on sub-Saharan African countries only, (2) the marginal effects of an analysis focusing on the sub-set of countries that have existed as independent nations since 1970, and (3) the effects of an analysis using alternative indicators for institutional quality and economic performance. For institutional quality, I have replaced the expropriation risk variable with an indicator measuring the overall democratic quality of the political system, also from Polity IV. The latter has been suggested to serve as a meta-institution for building good institutions (Rodrik, 2000). For economic performance, I have replaced per capita income with life expectancy (World Bank, 2016).

These checks show the main results to be moderately robust. The British Empire's effects on institutional quality disappear from countries the more time passes since their independence date regardless of the specification. For duration, results are similarly confirmed, with the slight exception of the effect of duration on democracy, which is not yet significant in the first years following independence. The democracy effect subsequently disappears again with country age. For the settlers dimension, the institutional quality effects are not significant for the entire age period, except when looking only at sub-Saharan Africa. In that particular specification, there is evidence of an emerging effect.

With regard to economic performance, the various dimensions also behave more or less as in the main analysis. British Empire and duration are not significant throughout the entire age period, with the exception of the British 
Figure 4. (Colour online) Robustness Institutional quality effects
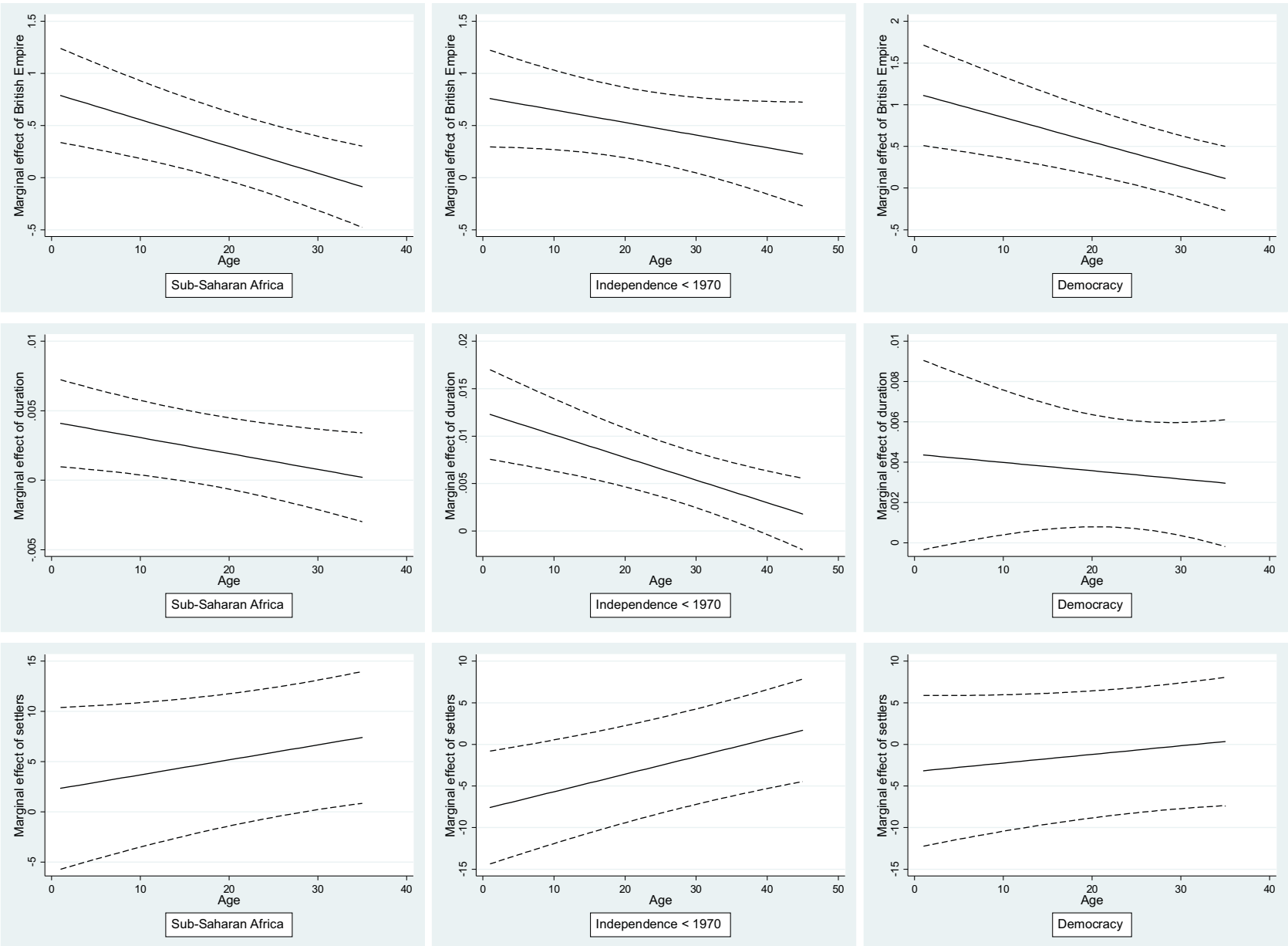

Notes: See Figure 2 
Figure 5. (Colour online) Robustness Economic Performance effects
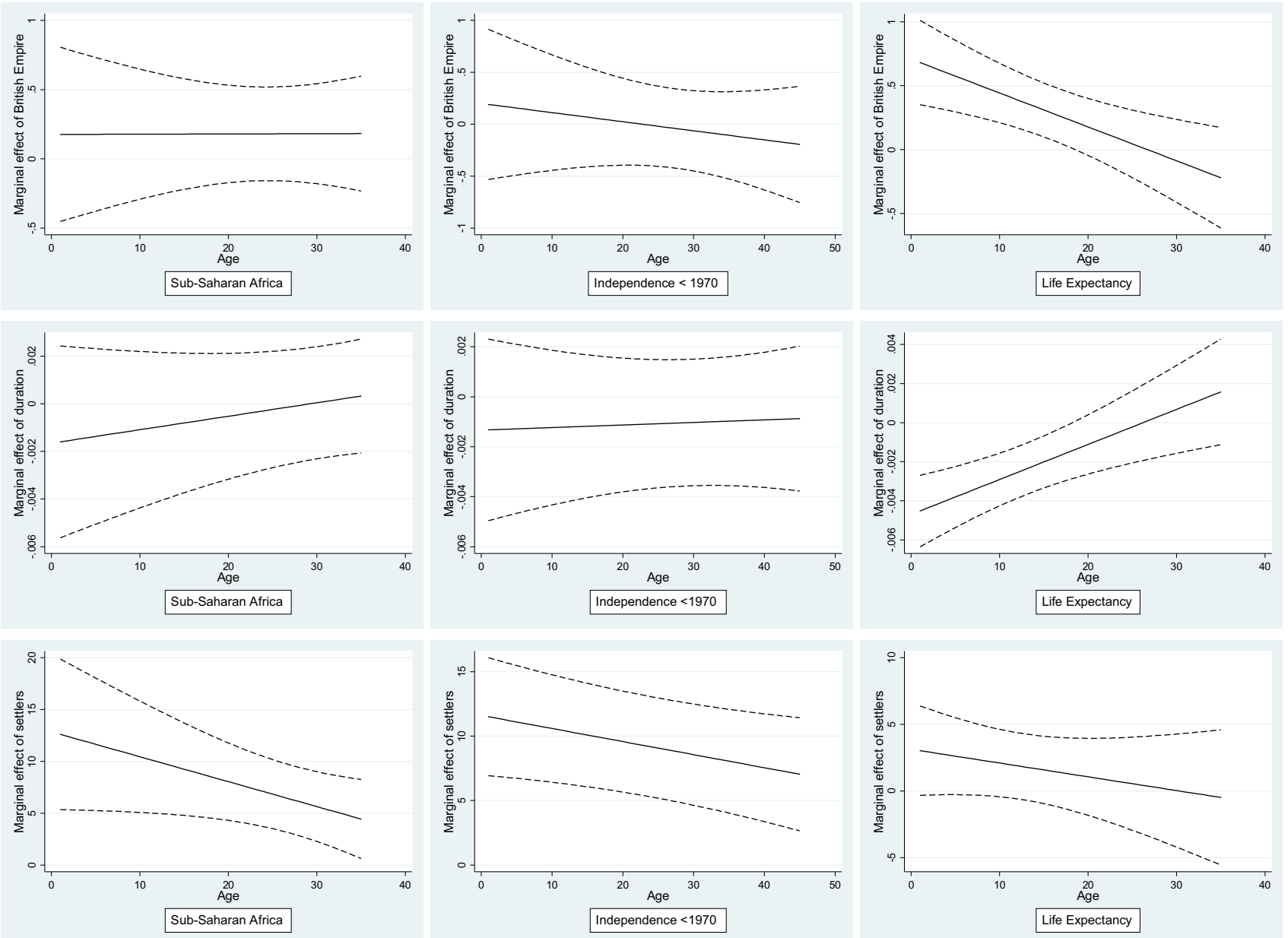

Notes: See Figure 2. 
Empire's effect on life expectancy, which starts out as positive but disappears with age. As in the main analysis, the settlers dimension consistently shows declining marginal effects, though not to the extent that it becomes insignificant at any point within the age period under study. All in all, these results largely confirm the earlier conclusions. Colonialism may have had a strong impact on societies, but this impact does not persist.

\section{Conclusion}

This paper has investigated the claim that colonialism has left enduring marks on African countries. Although I find that characteristics of colonial regimes are significant predictors of institutional quality shortly after independence, this effect disappears after that. Both yearly regressions and panel analysis suggest that in about three decades, the impact of colonial legacies on institutional quality has dropped to levels not significantly different from zero. For economic performance, I find support for an effect of the settlers' dimension of colonial legacy right after independence, but not for effects of the other dimensions. Even this settler effect declines with age, however, and in some specifications disappear within the studied time frame.

These results are in line with the thesis of Young (2004), who claims that the era of post-colonial states in Africa is largely over by the 1990s. Since independence, African states have followed an institutional and economic development path that is determined less and less by their colonial origins and more by their own characteristics and contemporary environment. Indeed, I show that some geographical and social features of the environment are becoming more prominent determinants of institutional development. Of course, this message applies to colonial legacy effects on institutional quality and per capita income only, which were the subject of this analysis. Even if its institutional effects have gone, colonialism may continue to leave an imprint on other outcomes, such as health, inequality or ownership structures. Note also that this paper has simply analysed a trend: the association between colonial legacies and institutional quality or per capita income declining after independence. Which mechanisms are responsible for this trend is subject to future research. Once we have a clearer idea about what enables post-colonial countries to escape from their historically shaped paths, it is possible to provide more tailored policy recommendations regarding institutional development in former African colonies.

My results provide ammunition against both the modern apologetics of colonialism claiming that colonial rule has left an enduring positive legacy for the colonized (Ferguson, 2012), and those who blame colonialism for all that goes wrong in Africa until today. Different forms of colonial rule led to different institutional conditions at the end of colonial rule. But rather than being persistent effects, these differences have all but disappeared by now. Whatever one's take on colonialism, this has important policy implications. With regard to 
institutional development, African countries are no longer constrained by their colonial history when choosing their paths for the future. Colonialism is neither a scapegoat nor a blessing for institutional and economic development, but mostly a thing of the past.

Theoretically, the finding that the institutional impact of colonialism has declined so strongly is also significant. Recent literature has stressed pathdependence and the resulting institutional persistence. One of the mechanisms of such path-dependence is the political-economic entrenchment of elites in societies, shaping the direction of institutional development in their own best interests. In this line of thought, a substantial shock to the distribution of power and institutional evolution such as colonial rule has created would put countries on a new, permanent trajectory of political-economic and institutional development (Acemoglu et al., 2005). My findings are inconsistent with this argument. Even an exceptionally large shock such as colonial rule wears off, and wears off relatively quickly. Both short-term idiosyncrasies and long-run determinants such as precolonial development and geography matter more than institutional path-dependence. While this may be bad news for the advocates of political-economic path-dependence for African countries, it is clearly a message of hope. It shows that their colonial past is not their future.

\section{References}

Acemoglu, D. and S. Johnson and (2005) 'Unbundling institutions', Journal of Political Economy, 113(5): 949-95.

Acemoglu, D. and J. A. Robinson (2013) Why Nations Fail: The origins of power, prosperity, and poverty, New York: Crown Business Publishing.

Acemoglu, D., S. Johnson and J. A. Robinson (2001) 'The colonial origins of comparative development: An empirical investigation', American Economic Review, 91(5): 1369401.

Acemoglu, D., S. Johnson and J. A. Robinson (2005) 'Institutions as a fundamental cause of long-run growth', in P. Aghion and S. Durlauf (eds) Handbook of Economic Growth Vol. 1, North Holland: Elsevier, pp. 385-472.

Ashraf, Q. and O. Galor (2013) 'The "Out of Africa" hypothesis, human genetic diversity, and comparative economic development', American Economic Review, 103(1): 1-46.

Bertocchi, G. and F. Canova (2002) 'Did colonization matter for growth? An empirical exploration into the historical causes of Africa's underdevelopment', European Economic Review, 46(10): 1851-71.

Conan Doyle, A. (1909) The Crime of the Congo, London: Hutchinson.

Conrad, J. (1899) 'Heart of darkness', Blackwood's Magazine, 165(2-4): 164-460.

Dell, M. (2010) 'The persistent effects of Peru's mining mita', Econometrica, 78(6): 1863-903.

Engerman, S. L. and K. L. Sokoloff (1997) 'Factor endowments, institutions, and differential paths of growth among new world economies', in S. Haber (ed.) How Latin America Fell Behind, Redwood City, CA: Stanford University Press, pp. 260-304.

Englebert, P. (2000) 'Pre-colonial institutions, post-colonial states, and economic development in tropical Africa', Political Research Quarterly, 53(1): 7-36. 
Feenstra, R. C., R. Inklaar and M. P. Timmer (2015) 'The next generation of the Penn World Table', American Economic Review, 105(10): 3150-82.

Ferguson, N. (2012) Empire: How Britain made the modern world, London: Penguin UK.

Fernández, R. and A. Fogli (2006) 'Fertility: The role of culture and family experience', Journal of the European Economic Association, 4(2-3): 552-61.

Feyrer, J. and B. Sacerdote (2009) 'Colonialism and modern income: islands as natural experiments', Review of Economics and Statistics, 91(2), 245-62.

Fieldhouse, D. K. (1966) The Colonial Empires: A comparative survey from the eighteenth century, London: Weidenfeld \& Nicolson.

Fincher, C. L., R. Thornhill, D. R. Murray and M. Schaller (2008) 'Pathogen prevalence predicts human cross-cultural variability in individualism/collectivism', Proceedings: Biological Sciences, 275(1640): 1279-85.

Fischer-Tiné, H. and M. Mann (2004) Colonialism as civilizing mission: Cultural ideology in British India, Cambridge: Anthem Press.

Gallup, J. L., J. D. Sachs and A. D. Mellinger (1999) 'Geography and economic development', International Regional Science Review, 22(2): 179-232.

Gennaioli, N. and I. Rainer (2007) 'The modern impact of precolonial centralization in Africa', Journal of Economic Growth, 12(3): 185-234.

Gorodnichenko, Y. and G. Roland (2016) 'Culture, institutions and the wealth of nations', Review of Economics and Statistics, Advanced Online Publication doi:10.1162/REST_a_00599

Grier, R. (1997) 'The effect of religion on economic development: A cross national study of 63 former colonies', Kyklos, 50(1): 47-62.

Grier, R. (1999) 'Colonial legacies and economic growth', Public Choice, 98(3-4): 317-35.

Kipling, R. (1899) 'The white man's burden', McClure's Magazine, 12(4): 290.

Klerman, D. M., P. G. Mahoney, H. Spamann and M. I. Weinstein (2011) 'Legal origin or colonial history?', Journal of Legal Analysis, 3(2): 379-409.

La Porta, R., F. Lopez-de-Silanes and A. Shleifer (2008) 'The economic consequences of legal origins', Journal of Economic Literature, 46(2): 285-332.

La Porta, R., F. Lopez-de-Silanes, A. Shleifer and R. W. Vishny (1997) 'Legal determinants of external finance', Journal of Finance, 52(3): 1131-50.

La Porta, R., F. Lopez-de-Silanes, A. Shleifer and R. W. Vishny (1998) 'Law and finance', Journal of Political Economy, 106(6): 1113-55.

Lange, M. (2004) 'British colonial legacies and political development', World Development, 32(6): 905-22.

Lange, M. (2009) Lineages of Despotism and Development: British colonialism and state power Chicago: University of Chicago Press.

Lee, A. and K. A. Schultz (2012) 'Comparing British and French colonial legacies: A discontinuity analysis of Cameroon', Quarterly Journal of Political Science, 7: 1-46.

Marshall, M., T. Gurr and K. Jaggers (2016) Polity IV project, political regime characteristics and transitions, 1800-2015. Retrieved from www.systemicpeace.org/inscrdata.html (accessed 10 June 2017).

Maseland, R. (2013) 'Parasitical cultures? The cultural origins of institutions and development', Journal of Economic Growth, 18(2): 109-36.

Michalopoulos, S. and E. Papaioannou (2013) 'Pre-colonial ethnic institutions and contemporary African development', Econometrica, 81(1): 113-52.

Michalopoulos, S. and E. Papaioannou (2016) 'The long-run effects of the scramble for Africa', American Economic Review, 106(7): 1802-48. 
Multatuli (1860) Max havelaar of de koffieveilingen van de nederlandsche handelsmaatschappy, Amsterdam: J. de Ruyter Publishers.

Murdock, G. P. (1967) 'Ethnographic atlas: A summary', Ethnology, 6(2): 109-236.

North, D. C. (2006) Understanding the process of economic change, Princeton, NJ: Princeton University Press.

North, D. C., J. J. Wallis and B. R. Weingast (2009) Violence and Social Orders: A conceptual framework for interpreting recorded human history. Cambridge: Cambridge University Press.

Nunn, N. (2008) 'The long-term effects of Africa's slave trades', Quarterly Journal of Economics, 123(1): 139-76.

Nunn, N. (2014) 'Historical development.' in P. Aghion and S. Durlauf (eds) Handbook of Economic Growth Vol. 2, North Holland: Elsevier, pp. 347-402.

Olson, M. (1993) 'Dictatorship, democracy, and development', American Political Science Review, 87(03): 567-76.

Putterman, L. and D. N. Weil (2010) 'Post-1500 population flows and the long-run determinants of economic growth and inequality', Quarterly Journal of Economics, 125(4): 1627-82.

Robinson, J.A, D. Acemoglu and S. Johnson (2003) 'An African success story: Botswana' in Dani Rodrik (ed.) In Search of Prosperity: Analytic Narratives on Economic Growth, Princeton: Princeton University Press, 80-119.

Rodrik, D. (2000) Institutions for high-quality growth: What they are and how to acquire them (w7540 ed.). Cambridge, MA: National Bureau of Economic Research.

Sachs, J. D. (2003) Institutions don't rule: Direct effects of geography on per capita income (w9490 ed.). Cambridge, MA: National Bureau of Economic Research.

Sokoloff, K. L. and S. L. Engerman (2000) 'History lessons: Institutions, factors endowments, and paths of development in the new world', Journal of Economic Perspectives, 14(3): 217-32.

Spolaore, E. and R. Wacziarg (2013) 'How deep are the roots of economic development?' Journal of Economic Literature, 51(2): 325-69.

Subramanian, A. (2013) 'The Mauritian success story and its lessons', in Augustin Fosu (ed.) Achieving Development Success: Strategies and Lessons from the Developing World, Oxford: Oxford University Press, pp. 204-31.

Williamson, O. E. (2000) 'The new institutional economics: Taking stock, looking ahead', Journal of Economic Literature, 38(3): 595-613.

World Bank. (2016) World development indicators. Retrieved from data.worldbank.org/datacatalog/world-development-indicators (accessed 10 June 2017).

Young, C. (2004) 'The end of the post-colonial state in Africa? Reflections on changing African political dynamics. African Affairs, 103(410): 23-49. 